\title{
REVIEW
}

\section{Underwater acoustics for ecosystem-based management: state of the science and proposals for ecosystem indicators}

\author{
Verena M. Trenkel ${ }^{1, *}$, Patrick H. Ressler ${ }^{2}$, Mike Jech $^{3}$, Marianna Giannoulaki ${ }^{4}$, \\ Chris Taylor 5
}

\author{
${ }^{1}$ Ifremer, rue de l'île d'Yeu, BP 21105, 44311 Nantes cedex 3, France \\ ${ }^{2}$ Alaska Fisheries Science Center, National Marine Fisheries Service, National Oceanic and \\ Atmospheric Administration (NOAA), 7600 Sand Point Way NE, Seattle, Washington 98115, USA \\ ${ }^{3}$ Northeast Fisheries Science Center, National Marine Fisheries Service, NOAA, 166 Water St., Woods Hole, \\ Massachusetts 02543, USA
}

${ }^{4}$ Hellenic Centre for Marine Research, Institute of Marine Biological Resources, Gournes, PO Box 2214, Iraklion, Greece

${ }^{5}$ Center for Coastal Fisheries and Habitat Research, National Centers for Coastal Ocean Science, National Ocean Service, NOAA, 101 Pivers Island Road, Beaufort, North Carolina 28557, USA

\begin{abstract}
Ecosystem-based management (EBM) requires more extensive information than singlespecies management. Active underwater acoustic methods provide a means of collecting a wealth of ecosystem information with high space-time resolution. Worldwide fisheries institutes and agencies are carrying out regular acoustic surveys covering many marine shelf ecosystems, but these data are underutilized. In addition, more and more acoustic data collected by vessels of opportunity are becoming available. To encourage their use for EBM, we provide a brief introduction to acoustic and complementary data collection methods in the water column, and review current and potential contributions to monitoring population abundance and biomass, spatial distributions, and predator-prey relationships. Further development of acoustics-derived indicators is needed. We review and propose indicators for assessing and monitoring zooplankton, population dynamics of fish and other nekton, and changes in diversity and food-web functioning. Acoustic methods have the potential to make a strong contribution to EBM. Evaluation of new indicators and suitable reference points in different ecosystems are the current challenges.
\end{abstract}

KEY WORDS: Active acoustics $\cdot$ Indicators $\cdot$ Ecosystem-based management

\section{INTRODUCTION}

Christensen et al. (1996) defined ecosystem-based management (EBM) as 'management driven by explicit goals, executed by policies, protocols, and practices, and made adaptable by monitoring and research based on our best understanding of the ecological interactions and processes necessary to sustain ecosystem structure and function'. Thus, transitioning from single-species fisheries management to
EBM will require increased information regarding the state and functioning of biotic ecosystem components (here, a taxon or group of taxa). A central tenet of EBM is the need to understand the ecological mechanisms and processes according to which the ecosystem is organized and the factors that modify them. These range from natural production, mortality, and climate change to human-induced fishing and environmental impacts. Management is then responsible for developing and funding appropriate 
survey programs to monitor the relevant ecosystem indicators.

Both active and passive acoustic methods are increasingly employed for exploring the marine environment (Foote 2009, Southall \& Nowacek 2009). As shown by Koslow (2009) in a recent review, underwater acoustics have provided a means of studying a wide range of ecological subjects, including benthic and pelagic habitats, predator-prey interactions, and fish recruitment. In parallel, for over 4 decades active acoustic methods have been used routinely for surveying the water column to derive single-species abundance indices (in numbers or weight) for direct input into stock assessments, as well as for fisheries research in general (Misund 1997, Fernandes et al. 2002, Simmonds \& MacLennan 2005). Routine monitoring typically focuses on species and taxonomic groups such as the small pelagic species of anchovy, sardine (e.g. Muiño et al. 2003, Paramo et al. 2003, Giannoulaki et al. 2008), and herring (e.g. Misund et al. 1997), as well as juvenile and adult stages of a range of commercial fish stocks (Nakken 2008, Koslow 2009, Oeberst et al. 2009) and zooplankton (Brierley et al. 1997). The advantage of active acoustic methods over other means of sampling marine zooplankton and fish is their high space-time resolution over wide scales (Godø 2009), as well as their capacity to simultaneously sample across several trophic levels, such as walleye pollock and their euphausiid prey (Ressler et al. in press), or large pelagic predator fishes like tuna and their micronekton prey (Bertrand et al. 2003). Acoustic methods can also yield data simultaneously on organisms and habitat. For example, Mackinson et al. (2004) extracted information on both sandeels and seabed sediment classes from a singlebeam echosounder. An overview of acoustic methods for carrying out benthic habitat classifications is provided in a report by ICES (2007a). Finally, acoustic methods are particularly advantageous for sampling abundant but patchily distributed organisms such as schooling fishes or micronekton, following small-scale oceanographic features (Bertrand et al. 2010).

Beyond single-species abundance indices, however, acoustic methods provide a means of collecting a wealth of other ecosystem information relevant to EBM. While indicators are regarded as the cornerstone of ecosystem-based fisheries management (Jennings 2007, Rochet \& Trenkel 2009), the use of acoustics-derived indicators is in its infancy. In this paper we provide an overview of acoustic methods, complementary data collection (i.e. sampling of target composition and habitat properties using nonacoustic tools), and the relevant ecosystem quantities and processes which can be studied with them. We then review and develop the concept of acousticsderived indicators and metrics for EBM. Examples of indicators are given, not as an exhaustive list, but to highlight cases where acoustics-based indicators can readily transition from current practice to EBM. We illustrate cases where acoustics-derived indicators and metrics can fill information gaps in EBM, and emphasize where further development would be fruitful.

\section{ACOUSTIC DATA COLLECTION}

\section{Sampling coverage and resolution}

Active acoustic methods and technologies are characterised by their capacity to sample over a very wide range of spatial scales and resolutions for each transmission (i.e. 'ping') compared to other underwater and surface sampling methods (Fig. 1). With the use of a sufficient range of acoustic frequencies, simultaneous sampling of organisms spanning body sizes from millimetres to metres is possible within seconds. Manned or unmanned surface and underwater vehicles can sample large areas in a relatively short time, while stationary deployments customarily monitor single locations over long periods. Active acoustic methods detect targets very well in the water column, but are less reliable in detecting targets on or near boundaries, such as the sea surface ('surface blind zone') or sea floor ('acoustic dead zone'; Ona \& Mitson 1996, Scalabrin et al. 2009). This is because the boundary generates a very large echo that can dominate echoes from biota. Multibeam systems and directional sonars (e.g. Trenkel et al. 2008, Korneliussen et al. 2009) and transducers deployed on alternative platforms (as opposed to scientific research vessels) such as autonomous underwater vehicles (AUVs; Fernandes et al. 2003, Scalabrin et al. 2009), buoys, and landers (Totland et al. 2009) offer improved capabilities in these situations, but do not entirely resolve the difficulties.

Fig. 1 shows the sampling resolution of some of the most commonly used instruments, but there is no limit to the imagination of innovative developers (Holliday 2009). Acoustic instruments are the only sampling devices that, unlike the selection or aggregation over depth accomplished by trawls, nets, etc., permit quasi-continuous sampling of fish and plankton throughout the water column. The resolution of acoustic measurements is similar to the spatial and temporal scales at which physical oceanographic 


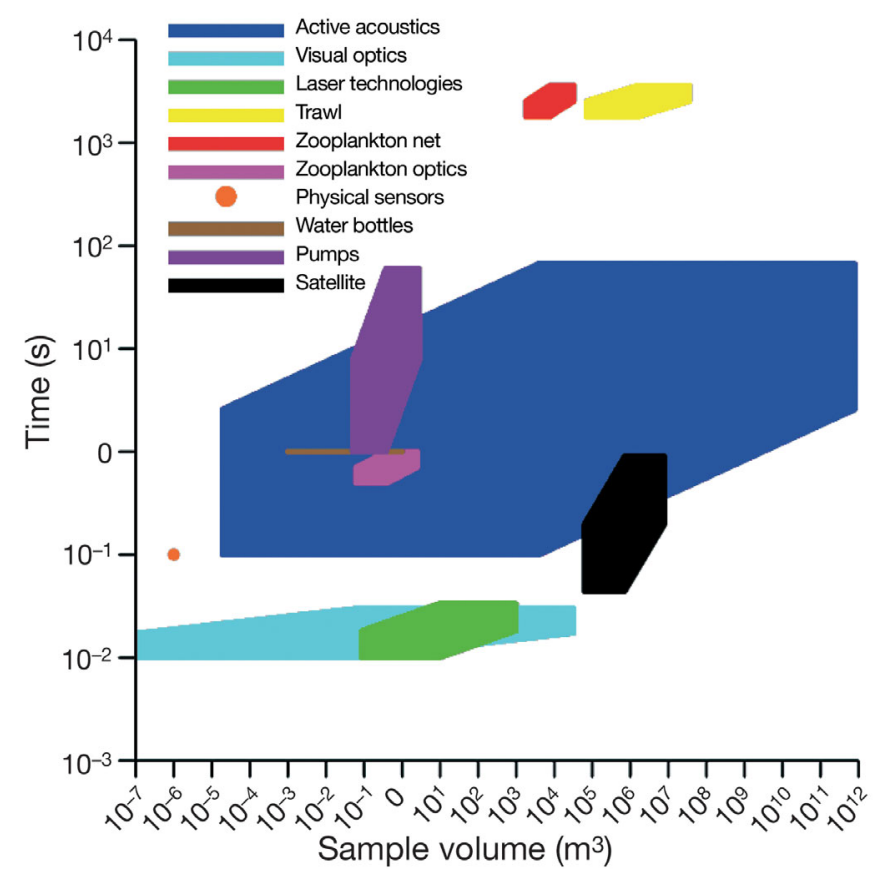

Fig. 1. Spatio-temporal scope of a single observation by various sampling devices and sensors. Resolution of the measurement is indicated by the lower-left side of the polygon and its range by the upper-right side. These represent the spatial extent of a single observation, not a time series (see description in Appendix 1)

data can be collected, a factor which has been exploited in spatially explicit analyses of acoustic data (e.g. Brandt et al. 1992, Holliday et al. 2009, Benoit-Bird et al. 2010, Moline et al. 2010).

\section{Coupling acoustic data with other sampling techniques}

Survey estimates are susceptible to biases introduced by fish and zooplankton behaviour. Examples of behaviours that alter the availability of fish to acoustic surveys include reaction of fish to sounds and survey vessels (Gerlotto \& Fréon 1992, Misund \& Aglen 1992, Popper et al. 2004, Handegard \& Tjøstheim 2005, De Robertis et al. 2008, ICES 2010, De Robertis \& Wilson 2011) and diel migrations (Lawson $\&$ Rose 1999). Coupling acoustic data with complementary data on size and species composition is often challenging, due to varying sampling selectivity and resolution among sampling methods, but it is necessary for proper interpretation of acoustic data, and comparisons among different complementary techniques can be insightful (McClatchie et al. 2000, Yule et al. 2007, Williams et al. 2010a).
The fundamental results of fisheries acoustics surveys and research are well-constrained solutions to the so-called 'inverse problem' for marine organisms (Holliday 1977a,b, Simmonds \& MacLennan 2005), where the number, size, and type of acoustic targets (fish and plankton) are estimated from acoustic volume backscatter $\left(S_{\mathrm{v}}\right.$; $\mathrm{dB}$ re $\left.1 \mathrm{~m}^{-1}\right)$ measurements (see MacLennan et al. 2002 for a review of acoustics terminology). The corresponding 'forward' problem involves computing the expected backscatter, given known numbers, sizes, and types of targets. A model that predicts the acoustic target strength $(\mathrm{TS} ; \mathrm{dB}$ re $1 \mathrm{~m}^{2}$ ) is required in either case. Although inverse methods can in principle be used to estimate abundance, size, and composition of fish and zooplankton from $S_{\mathrm{v}}$ measurements at multiple, appropriately selected frequencies (Holliday 1977a,b, Costello et al. 1989, Holliday et al. 1989), the problem is generally underdetermined (i.e. the number of unmeasured, or unknown, variables is greater than the number of measured, or known, variables) and complementary data collection methods are required to establish the size and species composition of dominant acoustic targets as well as to parameterize the scattering models. Complementary biological data are often collected with trawls or cameras, and complementary physical oceanographic measurements are typically made with CTD profilers or satellite data.

The appropriate complementary methods for use in determining acoustic target composition depend on the ecosystem component being studied. For acoustic surveys of fish, trawl catches contribute information on species composition, size, and age structure, which are necessary to estimate abundance indices (ICES 2000, Simmonds \& MacLennan 2005). They also contribute information on gender, maturity, reproductive potential, and diet. For zooplankton, acoustic information is often combined with species composition information from nets, pumps, and optical methods (Foote \& Stanton 2000, Wiebe \& Benfield 2003). Net sampling gear does not retain all sizes and species equally well (e.g. Clutter \& Anraku 1968, Bethke et al. 1999, Williams et al. 2010a), a fact that affects the corresponding acoustic estimates of abundance and distribution (Godø et al. 1998).

Optical methods have been used in conjunction with acoustic measurements for estimating species composition, size, and packing density, and for observing behaviour (e.g. Gledhill et al. 1996, Thomas \& Thorne 2003, Doray et al. 2007, Alvarez Colombo et al. 2009). While species identification is the most frequent use of optics in support of acoustic measurements, estimating fish size and behaviour with stereo- 
camera methods is also becoming more common (Long \& Aoyama 1985, Osborn 1997, Harvey et al. 2003, Williams et al. 2010b,c). For zooplankton and ichthyoplankton, optical instruments (e.g. cameras, video plankton recorders, optical plankton counters) are commonly towed or lowered through the water column and used for species identification and enumeration (Herman 1992, 2001; Benfield et al. 2007, Cowen \& Guigand 2008), although stationary instruments have also been used to observe behaviour (e.g. Jaffe et al. 1998). Since light energy is attenuated relatively rapidly in water, optical methods have a limited range compared to underwater acoustic methods, and when artificial light is required, avoidance and attraction by fish and zooplankton may significantly bias the observations (e.g. Sameoto et al. 1993, Benoit-Bird \& Au 2003a, Trenkel et al. 2004, Stoner et al. 2008).

\section{CONTRIBUTION OF ACOUSTICS TO ECOSYSTEM KNOWLEDGE AND EBM}

\section{Monitoring abundance and biomass}

Acoustic methods have been routinely used for assessing and monitoring the abundance and biomass of many pelagic and some semi-demersal fish and zooplankton species of commercial importance (Fernandes et al. 2002, Simmonds \& MacLennan 2005). Examples include Norwegian spring-spawning herring and herring in the Barents Sea (Toresen et al. 1998), anchovy in the Bay of Biscay (Massé 1996, Trenkel et al. 2009), sardine in the Spanish Mediterranean (Abad et al. 1998), walleye pollock in the Bering Sea (Karp \& Walters 1994, Honkalehto et al. 2009), and Antarctic krill (Hewitt \& Demer 2000, Kang et al. 2005). These long-standing acoustic surveys are the legacy of years of work in the field of fisheries acoustics and are fundamental to singlespecies stock assessment (e.g. ICES 2009, Cardinale et al. 2010), and they will continue to be important for EBM. However, biomass and abundance information for other ecosystem components which are not commercially important, but which may have a substantial influence on the food webs and ecosystems, are also needed.

Cost and logistical constraints prohibit the development of dedicated acoustic surveys for all taxa in an ecosystem. Fortunately, in many cases, indices can be derived from the same acoustic data collected for commercially important fish species. For example, De Robertis et al. (2010) demonstrated a classification method capable of distinguishing several acoustically important biological groups in the Bering Sea using data collected by acoustic and midwater trawl surveys of walleye pollock. Ressler et al. (in press) have applied this method to create an estimate of euphausiid biomass in the eastern Bering Sea using data collected during those same surveys. Euphausiids are a key component of the Bering Sea ecosystem as well as of many other ecosystems, comprising important prey for pollock and other groups of fish, birds, and marine mammals. The results of this index are being considered in the stock assessment process for pollock (Ianelli et al. 2010) and in a much broader assessment of the Bering Sea ecosystem (Zador \& Gaichas 2010). Brierley et al. (2005) and Alvarez Colombo et al. (2009) have made target-strength measurements and have proposed acoustic survey techniques for large jellyfish medusae, a group of organisms important in many ecosystems (Purcell et al. 2007, Suchman et al. 2008), but not regularly monitored through surveys.

If no suitable survey data exist, it may be possible and even cost-effective to use acoustic data collected by vessels of opportunity (ships other than dedicated acoustic research vessels; ICES 2007b), data collected in cooperative projects with fishing vessels, or other opportunistic data as a means of increasing the number of species for which abundance and distribution data exist. O'Driscoll et al. (2009) have monitored mesopelagic micronekton off the coast of New Zealand since 2001 using opportunistic acoustic data from bottom trawl surveys. There is considerable uncertainty in interpretation of this backscatter as an index of abundance for this group of organisms due to the mixed composition of the assemblage, but the investigators have pursued midwater trawling and target-strength modelling in an attempt to refine and better understand their index. Honkalehto et al. (2011) used a relative index of acoustic backscatter collected by chartered fishing vessels conducting a bottom trawl survey to increase the frequency of abundance estimates for pelagic walleye pollock in the eastern Bering Sea. The fishing vessels were unable to sample detected pelagic fish aggregations and were not equipped with multifrequency echosounders to aid in classification. The aggregations were classified, however, using historical data on species distribution, echogram morphology, and, when possible, by comparing the index with the results of traditional acoustic-trawl surveys in the region. Ressler et al. (2009) argued that monitoring acoustic backscatter using commercial fishing vessels at a suite of known habitat sites instead of the 
whole stock range (e.g. sentinel sites), accompanied by underwater camera sampling and trawling to monitor the composition of detected fish schools, would be sufficient to provide a relative index of abundance for the widow rockfish Sebastes entomelas, a depleted stock for which no reliable survey existed previously. Acoustic data of opportunity may also be a source of information on other, previously unmonitored, ecosystem components. Kloser et al. (2009) used data from vessels of opportunity to measure backscatter from midwater micronekton in the Tasman Sea; the composition of this backscatter was initially established through historical data and dedicated scientific sampling. The observed patterns over several years are intriguing, but Kloser et al. (2009) also noted the large uncertainty in interpreting this index of midwater micronekton until the variability in target composition is understood. They proposed strategies for routine monitoring using acoustic and optical gear deployed on a trawl. Lehodey et al. (2010) showed a promising correlation between model-estimated mid-trophic biomass and backscatter time series from acoustic doppler current profiler moorings, although more work is needed to properly characterize the biological composition of these backscatter layers (Radenac et al. 2010).

\section{Monitoring spatial distribution}

Current stock assessment models are usually not spatially explicit, but it is likely that future stock assessments and EBM will more fully incorporate spatial considerations (Quinn 2003, Methot 2009). The same survey data used for biomass and abundance provide information on the spatial distribution of fish and zooplankton populations. Woillez et al. (2007) describe indices of spatial distribution derived from acoustic data that could be used to monitor changes in distribution over time. The relationship between stock abundance and spatial spread provides information on potential changes of catchability with stock size (Petitgas 1998, Barange et al. 2009). Honkalehto et al. (2011) demonstrated that large-scale spatial patterns in midwater pollock distribution, as well as abundance, could be described using both dedicated acoustic-trawl survey data and acoustic data of opportunity from chartered commercial fishing vessels. The spatial distribution of fish biomass (possibly by species or groups) may also be a useful indicator in the study of marine reserve effects, particularly if estimates extend to either side of reserve or zoning boundaries.

\section{Predator-prey relationships and habitat requirements}

Knowledge of predator-prey relationships is necessary for constructing ecosystem models and assessing food web integrity (Livingston et al. 2005). The high spatial resolution of biological acoustic surveys and physical and biological oceanographic data, and recent development of powerful statistical tools for multivariate and spatial data analysis, can enable in-depth analysis of predator-prey processes. A growing number of studies has elucidated the spatial relationship between fish and their zooplankton prey (e.g. Swartzman et al. 1999, Bertrand et al. 2002, Grémillet et al. 2008) and marine mammals and their prey (Benoit-Bird et al. 2003b, 2009, Hazen et al. 2009b, Certain et al. 2011). Prey distributions mapped by acoustics matched to the physical environment have been used in spatially explicit models to characterize the pelagic habitat in terms of potential growth (Brandt et al. 1992). Ressler et al. (in press) used an acoustic estimate of euphausiid biomass on the Bering Sea shelf to conclude that pollock predation may be an important control on standing stock, and suggested that changes in springtime spatial distribution of euphausiids and pollock inferred from acoustic data by De Robertis \& Cokelet (in press) could mitigate the size of this predation impact.

An emerging number of habitat modelling studies has appeared in the last decade. These have combined acoustic with oceanographic data (e.g. Paramo \& Roa 2003, Petitgas et al. 2006, Peltonen et al. 2007, Lebourges-Dhaussy et al. 2009, Zwolinski et al. 2010) or with satellite-based environmental data (Bellido et al. 2008, Giannoulaki et al. 2008, Tugores et al. 2010, Zwolinski et al. 2011). Habitat characteristics and fish densities have been mapped at comparable extents and resolutions in coral reef and other coastal ecosystems by integrating the output of several sonar systems on multibeam hydrographic survey vessels (Kracker et al. 2011). Signal-processing advancements have allowed simultaneous extraction of information on fish in the water and bottom habitat from acoustic backscatter (Mackinson et al. 2004, Cutter et al. 2010).

Finally, the spatial distribution of organisms detectable with acoustic methods can in turn describe habitat conditions. For example, Bertrand et al. (2010) demonstrated that the vertical distribution of epipelagic organisms marked the position of the oxycline (the beginning of the oxygen minimum zone). Acoustic methods have been used for decades 
to observe physical oceanographic features such as internal waves and thermoclines when the organisms are passive tracers of these features (e.g. Andreyeva \& Makshtas 1977, Haury et al. 1979, Lavery et al. 2003).

\section{Current uses of acoustic survey data in EBM}

Abundance and biomass estimates from acoustic surveys can be used directly for stock assessment and management (e.g. Cotter et al. 2009), can be fed into stock assessment models (e.g. Quinn 2003, Methot 2009, Antonakakis et al. 2011) and ecosystem models such as Ecopath (Shannon et al. 2003, Coll et al. 2007, Tsagarakis et al. 2010), or can aid in the interpretation of model results. Potential indices of ecosystem processes and quantities, appropriate space and time scales, and the use of these indices in EBM are summarized in Table 1. Parameterisation of population and ecosystem models can be accomplished either by estimating model parameters singly from acoustic and other data or, jointly, by a model-fitting procedure. In either case the information must be on the appropriate space-time scale. Models used for assessment (i.e. for determination of state) require time series, while simulation models require only plausible parameter values or short time series for validation. Parameterised ecosystem models are increasingly used for scenario modelling, in particular for climate change and fishery management. Examples of these are Ecopath with Ecosim (Christensen et al. 2000, Pauly et al. 2000), Atlantis (Fulton et al. 2004, 2005), and Osmose (Shin \& Cury 2001).

\section{ACOUSTICS-DERIVED INDICATORS}

\section{Concepts and definitions}

Literature on the definition, use, and critique of indicators is abundant (e.g. Rochet \& Trenkel 2003, Rice \& Rochet 2005, Jennings 2007). Rochet \& Trenkel (2009) have proposed the following definitions:

'Indicator': a variable that quantifies how well an ecosystem (fishery in the original definition) is managed in relation to specified objectives.

'Metric': a variable that summarizes a process or pattern of interest in an exploited ecosystem.

The main difference between an indicator and a metric is that the former requires the definition of reference points, i.e. absolute reference values, to interpret measured indicator values, and the latter does not. One of the important challenges in the use of new indicators for EBM is the development of reference points. For most ecosystem indicators, apart from some population indicators, no reference points with a theoretical base are currently available (Rochet \& Trenkel 2003). For this reason, empirically based values have been suggested (Link et al. 2002, Rice 2009). A second important challenge is to understand how indicators might change with environmental change or the application of different management strategies. In the case of fisheries management, some form of regulation of fishing pressure has typically been the only action available to resource managers, but EBM may require consideration of coordination with management actions for other regulated pressures on the ecosystem (e.g. nutrient input to coastal marine systems; Caddy 2000). Detecting and understanding changes in the

Table 1. Overview of types of quantities and processes for which information can be extracted from active acoustic data, and their actual or potential use for ecosystem-based management (EBM). MY: multi-year monitoring time series; E: experimental process study of limited duration. The space and time scales indicated are those relevant for EBM

\begin{tabular}{|c|c|c|c|c|}
\hline $\begin{array}{l}\text { Quantity or process of } \\
\text { interest }\end{array}$ & $\begin{array}{l}\text { Spatial } \\
\text { scale }\end{array}$ & $\begin{array}{l}\text { Time } \\
\text { scale }\end{array}$ & Ecosystem components & EBM usage \\
\hline $\begin{array}{l}\text { Stock biomass or abundance } \\
\text { index }\end{array}$ & Stock & MY & Fish, krill & $\begin{array}{l}\text { Fish stock assessment; interpretation of } \\
\text { single-species results; ecosystem models }\end{array}$ \\
\hline Abundance index & Ecosystem & $\begin{array}{l}\text { MY } \\
\text { or E }\end{array}$ & $\begin{array}{l}\text { Zooplankton, jellyfish, } \\
\text { fish, species groups }\end{array}$ & $\begin{array}{l}\text { Resource (prey) assessment; ecosystem } \\
\text { models }\end{array}$ \\
\hline $\begin{array}{l}\text { Relationship between stock } \\
\text { biomass and spatial spread }\end{array}$ & Stock & MY & Fish & Monitoring catchability \\
\hline $\begin{array}{l}\text { Predator-prey spatial } \\
\text { relationships }\end{array}$ & $\begin{array}{l}\text { Local or } \\
\text { ecosystem }\end{array}$ & $\mathrm{E}$ & $\begin{array}{l}\text { Fish-zooplankton inter- } \\
\text { actions, marine mammal- } \\
\text { zooplankton interactions }\end{array}$ & $\begin{array}{l}\text { Identifying and monitoring food web } \\
\text { structure; ecosystem models }\end{array}$ \\
\hline $\begin{array}{l}\text { Spatial distribution-physical } \\
\text { habitat relationship }\end{array}$ & Ecosystem & $\mathrm{E}$ & $\begin{array}{l}\text { Fish, zooplankton, } \\
\text { hydrography/substrate }\end{array}$ & $\begin{array}{l}\text { Ecosystem models; habitat mapping; } \\
\text { climate change scenarios; spatial } \\
\text { management }\end{array}$ \\
\hline
\end{tabular}


environment is challenging in itself, but understanding the resulting impact on a complex ecosystem and on associated ecosystem indicators may be even more difficult. In the absence of reference points, time trends in metrics have provided useful insights into ecosystem dynamics (Rochet et al. 2005, Rochet et al. 2010). However, this does not dispense with the need to have interpretable metrics in the first place.

\section{Metrics and indicators}

Up to now, as has been discussed, acousticsderived indicators have primarily been used in the context of single-species management. Very little use has been made of acoustic data for deriving other indicators, despite the recognised potential for doing this. Indicators and metrics that can be calculated with traditional technology and for which time series already exist are used as a starting point in the following discussion. Future instrument developments will enlarge this list. For each indicator, the theoretical basis, possible reference points, and the expected direct effects of fishing and environmental change are considered (Table 2).

\section{Status of commercial and other species}

Acoustics-derived biomass and abundance indices have long been used in single-stock assessments and will remain important for EBM. Species classification issues determine the achievable accuracy and precision of these indices, where reliable estimates are achieved when species are in mono-specific aggregations, as described above, and accuracy decreases as species co-occur. For use as indicators to monitor management performance, reference points can be derived as relative values with respect to some period in the past, provided the time series covers a period of satisfactory stock status (Table 2). An increase in fishing will decrease biomass of the target species, while the expected effects of changing environmental conditions are difficult to determine.

Mean body length is an established indicator, and its expected change under fishing pressure is well understood (Table 2, Shin et al. 2005). However, natural fluctuations in length unrelated to fishing pressure, such as the temporal decrease in mean length with increasing recruitment, often reduce the utility of length as an indicator; this is largely the reason why no reference point for mean length is currently used. Acoustically, length can be derived from target-

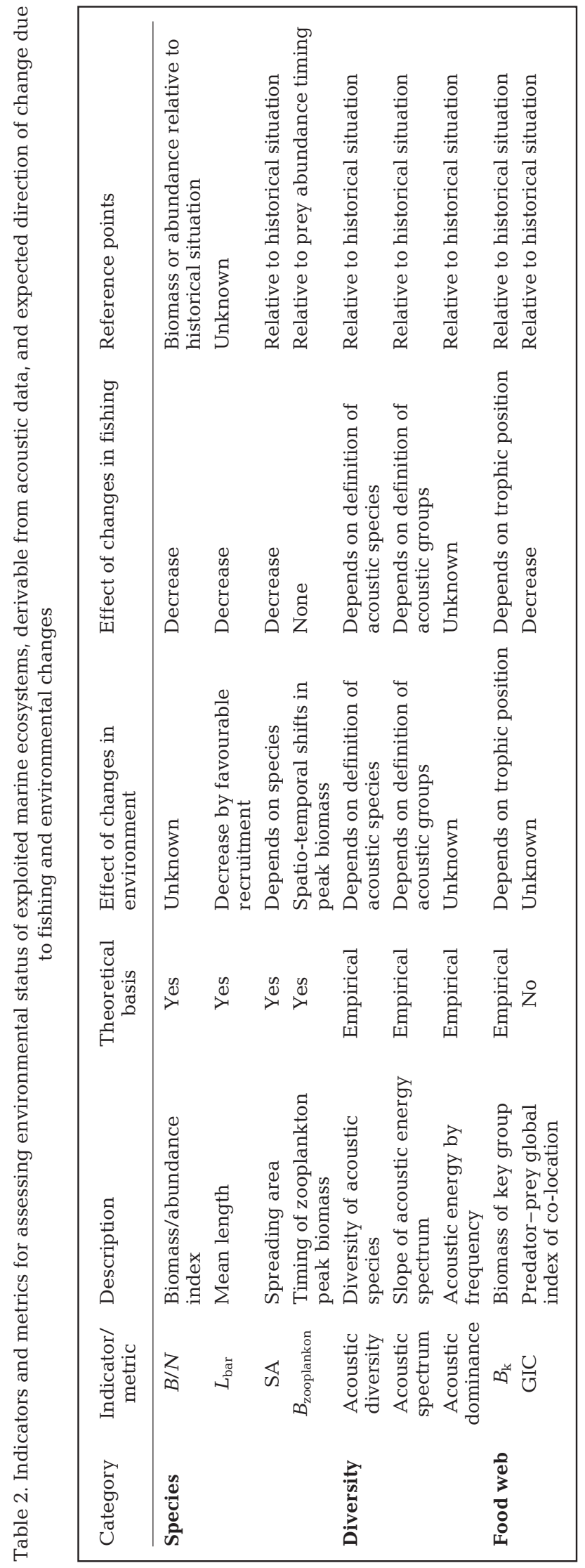


strength measurements, or from using multiple frequencies and the inverse method (though the frequencies needed to accomplish this for fish with swim bladders are lower than those typically used in fisheries surveys). Similarly, weight can be empirically derived if both target-strength:length and length:biomass relations are known. In certain cases, mean length and weight in the population can be derived using trawl information or recently developed techniques for determining fish size from acoustics information alone (e.g. Chu et al. 2003). More research and analysis is needed to generate reference points for these potential length-based indicators.

The spatial range of a species and how it is distributed within that range has the potential to be a useful indicator. The 'spreading area' is a measure of the spatial occupancy of a population (Table 2, Woillez et al. 2007). Its meaning as an indicator comes from the existence of abundance-occupancy (A-O) relationships that describe how individuals maintain distance between each other in relation to the total number of individuals, and it can be seen as a reflection of intraspecific competition for a limited resource combined with social and reproductive behaviours (Gaston et al. 2000). A-O relationships for many fish species reach an asymptote (Frisk et al. 2011). Thus, apart from situations with very high stock abundance, the spreading area can provide an indication of population size. In addition, it may identify situations where a species has increased its catchability through spatial contraction. At this time, a theoretical reference point is not available. Further studies are required to examine how spreading area varies with population size, intraspecific competition and environmental conditions, and to ultimately provide an index for the status of the stock and its vulnerability to environmental conditions. Acoustic methods serve very well in making these kinds of measurements and can be used to examine the usefulness of spreading area or other measures of spatial occupancy.

Spatial and, in particular, temporal mismatch between juvenile predator stages and their zooplankton prey can lead to recruitment failure due to starvation (Cushing's 'mismatch hypothesis'), though absolute prey abundance is also important (Durant et al. 2005). Acoustics can provide estimates of zooplankton peak abundance, which can be related to production timing, and spatial coverage, which might then be used for forecasting recruitment strength. Reference points could be based on optimal spatio-temporal predator-prey overlap.

\section{Biodiversity changes}

Species diversity indices such as the Shannon index are used in combination with species richness to summarize the distribution of individuals among species (see discussion in Rochet \& Trenkel 2003 regarding their suitability as EBM indicators). In the absence of species-specific information, surrogates for species, such as coarser taxonomic groupings, other species in the same genus, or other indirect proxies of species richness, have been used. Examples of non-taxonomic proxies are the remotesensing-derived terrestrial surrogate species estimators used for terrestrial vegetation applications (see review in Rocchini et al. 2010) and the analysis of phytoplankton pigment ratios to rapidly index phytoplankton taxonomic composition (Mackey et al. 1996, Jeffrey et al. 1999). For terrestrial fauna, the relationship between species habitat preferences and species distribution are commonly used to derive indirect habitat-based biodiversity estimators (see review in Leyequien et al. 2007). Recently, Mellin et al. (2011) reviewed the literature for evaluating the effectiveness of taxonomic- and abiotic-based surrogates for predicting marine biodiversity indicators but did not find a single study for the pelagic domain.

As described above, acoustic data contain information on species or size groups (roughly corresponding to trophic levels) which can serve as surrogates for species in the computation of index values. Further refinement is possible when data are collected for several appropriately chosen echosounder frequencies due to the distinct frequency-response curve (i.e. backscattered energy depending on frequency) of organism groups such as zooplankton, fish with swim bladders, and fish without swim bladders. Godø (2009) suggested deriving ecosystem indicators from the multi-frequency backscattering spectrum, but this has not been done so far. A possible approach for deriving 'acoustic' diversity indices may be to derive information on surrogate species from multi-frequency acoustic backscatter data and then calculate a single acoustic diversity index by combining the surrogate species information (Table 2). Reference points, or maps in the case of spatial calculations, could then be derived from historical data sets. It might also be possible to develop acoustic species richness estimators which are indicative of actual species richness, similar to what is done for terrestrial remote sensing data. Finally, an alternative to single-valued diversity indices are dominance curves (Clarke 1990), which in this context might be a curve of the proportion of total energy per frequency (band) plotted versus the rank of that frequency (Table 2). 
The use of backscattering spectra similar to size spectra may be possible. The slope of the size spectrum is a widely used community indicator (see overview in Shin et al. 2005). The size spectrum is defined as ln (abundance) linearly regressed against ln (size class). Abundance and biomass versions exist. There is theoretical and empirical evidence that the slope increases under the impact of fishing. Theoretically this is explained by the fact that fishing removes larger individuals, and indirect effects can lead to increases of their smaller prey. There might be a parallel argument here if meaningful acoustic surrogate species groups can be defined (Table 2). Further studies are required to demonstrate and evaluate the usefulness of such acoustic indices of diversity and multifrequency dominance curves to describe community changes and to set reference points.

\section{Food web functioning}

Abundance indices for key species groups can be related to food web changes in ecosystem functioning (Table 2, Livingston et al. 2005). In many food webs, gross anatomical differences in organisms accompany changes in trophic level. For example, a generic food web has phytoplankton, zooplankton, forage fishes, piscivores, apex predators, and humans as individual levels. Acoustic methods are generally successful at classifying acoustic backscatter to trophic level (e.g. Goss et al. 1998, Kang et al. 2002, Korneliussen \& Ona 2003, Jech \& Michaels 2006, De Robertis \& Cokelet in press, Ressler et al. in press). Acoustic methods are less successful at separating species, or 'intra-trophic-level' classification, and this is an area of intense research in fisheries acoustics. Expected changes in trophic dynamics under the impact of fishing depend on the trophic position of these species and the trophic level at which fishing occurs (Rochet et al. 2010). For example, 'fishing down' the food web (a gradual change in the trophic level of commercial landings from high to low; Pauly et al. 1998) should be detectable using acoustic methods. Similarly, for the expected impacts of changes in environmental conditions, future research might enable relative reference points to be derived for this indicator.

Predator-prey relationships structure food webs on different spatio-temporal scales. Using high-resolution acoustic information, Benoit-Bird \& Au (2003b) showed that spinner dolphins followed the diel horizontal and vertical migration of their nekton prey; key to this behavioural study was the simultaneous observation of both predators and prey. More general predator-prey patterns are observable on a larger spatio-temporal scale. Grémillet et al. (2008) detected a spatial mismatch between zooplankton and small pelagics (sardine and anchovy) off the coast of South Africa. They interpreted this as the consequence of a regime shift which has modified the ecosystem. In the Bay of Biscay the mesoscale (dozens of $\mathrm{km}$ ) spatial distribution of anchovy displayed significant correlation with plankton communities commonly found in river plumes and in the southern coastal areas (Petitgas et al. 2006). Thus changes in spatial overlap at different spatio-temporal scales might indicate ecosystem changes, which could be subsequent to changes in environmental conditions. However, as large-scale spatial overlap between fish predator-prey pairs can vary strongly among years (Kempf et al. 2010), conclusions regarding general food web changes might have to be based on several species. As noted previously, various indices of spatial overlap exist (see review in Woillez et al. 2007), including the global index of co-location proposed by Bez \& Rivoirard (2000); utilizing data from acoustic surveys, the larger-scale spatial overlap between species (fish) or species groups (zooplankton) could be estimated. The increase of fishing pressure on one species or set of species might be expected to reduce the spatial overlap with other species since it decreases the overall spatial distribution range of that group. Effects of environmental conditions are more complex and potentially less intuitive. This is because, as environmental conditions change, they may affect the spatial distribution and abundance of multiple species but not necessarily in the same way for each species. Acoustic surveys during periods of acute environmental stress, such as hypoxia, have provided more clear insight into overlap of species or trophic levels and potential impacts to food webs. Taylor \& Rand (2003), Taylor et al. (2007), and Hazen et al. (2009a) have shown that vertical distributions of fish are strongly affected by stratification and hypoxia, whereas their zooplankton prey have higher tolerance and possibly use the hypoxic zones as a refuge from predation.

\section{CONCLUSIONS AND RECOMMENDATIONS}

Acoustic sampling methods have clear advantages as well as limitations. Their usefulness in monitoring the abundance of commercially important pelagic fishes and zooplankton is well established. To support EBM, the application of these techniques to other important species and species groups should 
be explored, keeping in mind that resources for additional survey efforts are limited. The techniques described here are most effective for pelagic and semidemersal species. Backscatter classification, groundtruth sampling, and determination of size and taxonomic composition of dominant acoustic scatterers must be pursued with as much rigor as possible by developers and users of acoustic methods. Sampling with complementary technologies such as nets, trawls, and optics to define size, species, gender, maturity, and age composition will continue to play an important role. A clear understanding of the capabilities of acoustic measurements will determine how useful any indicators derived from these data will be. For example, acoustic data can be categorized as good, fair, or poor, as follows:

Good: calibrated acoustic backscatter, robust classification of targets, established target-strength models for organisms, and conversion of backscatter into ecologically relevant units (e.g. biomass or abundance by size and taxon). This is the case for a scientific acoustic survey.

Fair: calibrated backscatter, good description of the dominant acoustic targets and how this target composition varies over time and space. This would be the case for acoustic backscatter from a mixture of midwater micronekton measured by vessels of opportunity, accompanied by net sampling of the composition of the scattering layers.

Poor: uncalibrated backscatter, targets unknown. This would be the case for acoustic data from vessels of opportunity or buoys with no complementary sampling and no way to infer the composition of the backscatter based on prior knowledge of or comparisons with similar ecosystems. It is currently nearly useless for developing indicators for EBM.

Our recommendations for development and application of acoustic indicators for EBM may be summarized as follows:

(1) Extend acoustic indices of biomass and abundance to other species and species groups in the ecosystem. The most commonly used indicator in fisheries stock assessment and management is biomass, which is used for stock modelling and is evaluated relative to a reference point that depends on the management objective. There is no reason why these and other potential stock or trophic-level indicators cannot be carefully extended to other species and species groups.

(2) Explore the use of acoustic methods for indexing properties other than biomass and abundance. The same acoustic data used for biomass estimation can be used to describe other properties of fish populations, such as spatial distribution, occupancy, body length, and habitat conditions, all of which may become more important in EBM than they have been in single-species management. Diversity and food web considerations are clearly gaining in importance, and it therefore seems timely to develop acoustics-derived indicators for food webs and assemblages. We have provided ideas for future research on this topic.

(3) Develop reference points for indicators so that they can be properly interpreted for EBM. Two major challenges remain: (1) to clearly define the goals of EBM, and (2) to establish acceptable reference points for potential indicators (other than stock biomass). With regard to the second challenge, especially, we propose that empirical reference points should be defined for new indicators, and the behaviour of those indicators under different hypothetical pressures on the ecosystem (fishing and climate change) should be tested using the best information available. For example, an indicator of fish-prey (e.g. zooplankton) abundance derived from acoustic data should be evaluated against a predefined abundance level that corresponds either to a certain point in the available time series that presents specific characteristics, or to a critical level of biomass. Expected changes in this index due to the variation in the abundance of predators, to fishing, and to environmental changes should also be taken into consideration. As new information and additional observations are gathered, these reference points and scenarios should be re-evaluated and revised in order to ensure that the indicator is being interpreted correctly in its EBM context. Comparative studies of similar indicators, reference points, and models used for EBM in different ecosystems will be useful.

The synthesis of technique, measurement, and application that we propose here is something that scientists who develop and use acoustics technology to study marine organisms, as well as analysts and modellers who use acoustic data for assessment and management, must work together to achieve.

Acknowledgements. This review is the fruit of discussions during the ICES Working Group on Fisheries Acoustics Science and Technology, for which we thank all group members. The findings and conclusions in the paper are those of the authors and do not necessarily represent the views of NOAA's National Marine Fisheries Service.

\section{LITERATURE CITED}

Abad R, Miquel J, Iglesias M, Álvarez F (1998) Acoustic estimation of abundance and distribution of sardine in the northwestern Mediterranean. Fish Res 34:239-245 
Alvarez Colombo G, Benović A, Malej A, Lučić D and others (2009) Acoustic survey of a jellyfish-dominated ecosystem (Mljet Island, Croatia). Hydrobiologia 616:99-111

Andreyeva IB, Makshtas YP (1977) Internal waves and sound scattering layers in the thermocline. Oceanology (Mosc) 17:287-289

Antonakakis K, Giannoulaki M, Machias A, Somarakis S, Sanchez S, Ibaibarriaga L, Uriarte A (2011) Assessment of the sardine (Sardina pilchardus Walbaum, 1792) fishery in the eastern Mediterranean basin (North Aegean Sea). Medit Mar Sci 12:233-257

Azarovitz TR (1981) A brief historical review of Woods Hole Laboratory trawl survey time series. In: Doubleday WG, Rivard D (eds) Bottom trawl surveys, spec. pub. 58. Fisheries and Oceans Canada, Ottawa, p 62-67

Baggeroer AB, Birdsall TG, Clark C, Colosi JA and others (1998) Ocean climate change: comparison of acoustic tomography, satellite altimetry, and modeling. Science 281:1327-1332

Barange MJ, Coetzee A, Takasuka K, Hill M and others (2009) Habitat expansion and contraction in anchovy and sardine populations. Prog Oceanogr 83:251-260

Barbini R, Colao F, Fantoni R, Fiorani L, Kolodnikova N, Palucci A (2006) Laser remote sensing calibration of ocean color satellite data. Ann Geophys 49:35-43

Bellido JM, Brown AM, Valavanis VD, Giráldez A, Pierce GJ, Iglesias M, Palialexis A (2008) Identifying essential fish habitat for small pelagic species in Spanish Mediterranean waters. Hydrobiologia 612:171-184

Benfield MC, Grosjean P, Culverhouse PF, Irigoien X and others (2007) RAPID: research on automated plankton identification. Oceanography (Wash DC) 20:172-187

Benoit-Bird KJ, Au WWL (2003a) Echo strength and density structure of Hawaiian mesopelagic boundary community patches. J Acoust Soc Am 114:1888-1897

Benoit-Bird KJ, Au WWL (2003b) Prey dynamics affect foraging by a pelagic predator (Stenella longirostris) over a range of spatial and temporal scales. Behav Ecol Sociobiol 53:364-373

Benoit-Bird KJ, Dahood AD, Wursig B (2009) Using active acoustics to compare lunar effects on predator-prey behavior in two marine mammal species. Mar Ecol Prog Ser 395:119-135

Benoit-Bird KJ, Moline MA, Waluk CM, Robbins IC (2010) Integrated measurements of acoustical and optical thin layers I: vertical scales of association. Cont Shelf Res 30: $17-28$

Bertrand A, Bard FX, Josse E (2002) Tuna food habits related to the micronekton distribution in French Polynesia. Mar Biol 140:1023-1037

Bertrand A, Josse E, Bach P, Dagorn L (2003) Acoustics for ecosystem research: lessons and perspectives from a scientific programme focusing on tuna-environment relationships. Aquat Living Resour 16:197-203

Bertrand A, Ballón M, Chaigneau M (2010) Acoustic observation of living organisms reveals the upper limit of the Oxygen Minimum Zone. PLoS ONE 5: e10330

Bethke E, Arrhenius F, Cardinale M, Håkansson N (1999) Comparison of the selectivity of three pelagic sampling trawls in a hydroacoustic survey. Fish Res 44:15-23

Bez N, Rivoirard J (2000) Indices of collocation between populations. In: Checkley DM, Hunter JR, Motos L, van der Lingen CD (eds) Report of a workshop on the use of Continuous Underway Fish Egg Sampler (CUFES) for map- ping spawning habitat of pelagic fish, GLOBEC rept. no. 14. GLOBEC International Project Office, Plymouth, p 48-52

Brandt SB, Mason DM, Patrick EV (1992) Spatially-explicit models of fish growth rate. Fisheries 17:23-35

Brierley AS, Watkins JL, Murray AWA (1997) Interannual variability in krill abundance at South Georgia. Mar Ecol Prog Ser 150:87-98

Brierley AS, Boyer DC, Axelsen BE, Lynam CP, Sparks CAJ, Boyer HJ, Gibbons MJ (2005) Towards the acoustic estimation of jellyfish abundance. Mar Ecol Prog Ser 295: $105-111$

Caddy JF (2000) Marine catchment basin effects versus impacts of fisheries on semi-enclosed seas. ICES J Mar Sci 57:628-640

Cardinale M, Cheilari A, Ratz HJ (2010) Report of the SGMED-09-02 Working Group on the Mediterranean Part I. Scientific, Technical and Economic Committee for Fisheries (STECF), 4-8 June 2010, Iraklion, Greece

Certain G, Masse J, Van Canneyt O, Petitgas P, Doremus G, Santos MB, Ridoux V (2011) Investigating the coupling between small pelagic fish and marine top predators using data collected from ecosystem-based surveys. Mar Ecol Prog Ser 422:23-39

Christensen NL, Bartuska AM, Brown JH, Carpenter S and others (1996) The report of the Ecological Society of America committee on the scientific basis for ecosystem management. Ecol Appl 6:665-691

Christensen V, Walters CJ, Pauly D (2000) Ecopath with Ecosim: a user's guide. University of British Columbia, Vancouver, BC

> Chu D, Jech JM, Lavery A (2003) Inference of geometrical and behavioural parameters of individual fish from echotrace-analysis. Deep-Sea Res I 50:515-527

> Churnside JH, Wilson JJ, Tatarskii VV (2001) Airborne lidar for fisheries applications. Opt Eng 40:406-414

> Clarke KR (1990) Comparisons of dominance curves. J Exp Mar Biol Ecol 138:143-157

Clutter RI, Anraku M (1968) Avoidance of samplers. In: Trauter DJ (ed) Zooplankton sampling: monographs on oceanographic methodology 2. UNESCO, Paris p 57-76

Coll M, Santojanni A, Palomera I, Tudela S, Arneri E (2007) An ecological model of the Northern and Central Adriatic Sea: analysis of ecosystem structure and fishing impacts. J Mar Syst 67:119-154

> Costello JH, Pieper RE, Holliday DV (1989) Comparison of acoustic and pump sampling techniques for the analysis of zooplankton distributions. J Plankton Res 11:703-709

> Cotter J, Petitgas P, Abella A, Apostolaki P and others (2009) Towards an ecosystem approach to fisheries management (EAFM) when trawl surveys provide the main source of information. Aquat Living Resour 22:243-254

> Cowen RK, Guigand CM (2008) In situ Ichthyoplankton Imaging System (ISIIS): system design and preliminary results. Limnol Oceanogr Methods 6:126-132

> Cutter GR Jr, Berger L, Demer DA (2010) A comparison of bathymetry mapped with the Simrad ME70 multibeam echosounder operated in bathymetric and fisheries modes. ICES J Mar Sci 67:1301-1309

De Robertis A, Cokelet ED (in press) Fish and macrozooplankton distribution in ice-covered and open-water areas of the eastern Bering Sea. Deep-Sea Res II

> De Robertis A, Hjellvik V, Williamson NJ, Wilson CD (2008) Silent ships do not always encounter more fish: compari- 
son of acoustic backscatter recorded by a noise-reduced and a conventional research vessel. ICES J Mar Sci 65: 623-635

De Robertis A, Wilson CD (2011) Silent ships do not always encounter more fish (revisited): comparison of acoustic backscatter from walleye pollock recorded by a noisereduced and a conventional research vessel in the eastern Bering Sea. ICES J Mar Sci 68:2229-2239

De Robertis A, McKelvey DR, Ressler PH (2010) Development and application of an empirical multifrequency method for backscatter classification. Can J Fish Aquat Sci 67:1459-1474

> Doray M, Josse E, Gervain P, Reynal L, Chantrel J (2007) Joint use of echosounding, fishing and video techniques to assess the structure of fish aggregations around moored Fish Aggregating Devices in Martinique (Lesser Antilles). Aquat Living Resour 20:357-366

> Durant MJ, Hjermann DØ, Anker-Nilssen T, Beaugrand G, Mysterud A, Pettorelli N, Stenseth NC (2005) Timing and abundance as key mechanisms affecting trophic interactions in variable environments. Ecol Lett 8:952-958

Fernandes PG, Gerlotto F, Holliday DV, Nakken O, Simmonds EJ (2002) Acoustic applications in fisheries sciences: the ICES contribution. ICES J Mar Sci 215:483-492

Fernandes PG, Stevenson P, Brierley AS, Armstrong F, Simmonds EJ (2003) Autonomous underwater vehicles: future platforms for fisheries acoustics. ICES J Mar Sci 60:684-691

Foote KG (2009) Acoustic methods: brief review and prospects for advancing fisheries research. In: Beamish RJ, Rothschild BJ (eds) The future of fisheries science in North America. Springer Science, Dordrecht, p 313-343

Foote KG, Stanton TK (2000) Acoustical methods. In: Harris RP, Wiebe PH, Lenz J, Skjoldal HR, Huntley M (eds) Zooplankton methodology manual. Academic Press, San Diego, CA, p 223-253

> Frisk MG, Duplisea DE, Trenkel VM (2011) Exploring the abundance-occupancy relationships for the Georges Bank finfish and shellfish community from 1963 to 2006. Ecol Appl 21:227-240

> Fulton EA, Parslow JS, Smith ADM, Johnson CR (2004) Biogeochemical marine ecosystem models II: the effect of physiological detail on model performance. Ecol Model 173:371-406

Fulton EA, Smith ADM, Punt AE (2005) Which ecological indicators can robustly detect effects of fishing? ICES J Mar Sci 62:540-551

Gaston KJ, Blackburn TM, Greenwood JJD, Gregory RD, Quinn RM, Lawton JH (2000) Abundance-occupancy relationships. J Appl Ecol 37:39-59

Gerlotto F, Fréon P (1992) Some elements on vertical avoidance of fish schools to a vessel during acoustic surveys. Fish Res 14:251-259

Giannoulaki M, Valavanis VD, Palialexis A, Tsagarakis K, Machias A, Somarakis S, Papaconstantinou C (2008) Modelling the presence of anchovy Engraulis encrasicolus in the Aegean Sea during early summer, based on satellite environmental data. Hydrobiologia 612:225-240

Gledhill CT, Lyczkowski-Shultz J, Rademacher K, Kargard E, Christ G, Grace MA (1996) Evaluation of video and acoustic index methods for assessing reef-fish populations. ICES J Mar Sci 53:483-485

Godø OR (2009) Technology answers to the requirements set by the ecosystem approach. In: Beamish RJ, Roth- schild BJ (eds) The future of fisheries science in North America. Springer Science, Dordrecht, p 373-403

> Godø OR, Karp WA, Totland A (1998) Effects of trawl sampling variability on precision of acoustic abundance estimates of gadoids from the Barents Sea and the Gulf of Alaska. ICES J Mar Sci 55:86-94

Goss C, Rodhouse P, Watkins JL, Brierley AS (1998) Attribution of acoustic echoes to squid in the South Atlantic. CCAMLR Science 5:259-271

> Grémillet D, Lewis S, Drapeau L, van Der Lingen CD and others (2008) Spatial match-mismatch in the Benguela upwelling zone: Should we expect chlorophyll and seasurface temperature to predict marine predator distributions? J Appl Ecol 45:610-621

Handegard NO, Tjøstheim D (2005) When fish meet a trawling vessel: examining the behaviour of gadoids using a free-floating buoy and acoustic split-beam tracking. Can J Fish Aquat Sci 62:2409-2422

- Harvey E, Cappo M, Shortis M, Robson S, Buchanan J, Speare P (2003) The accuracy and precision of underwater length and maximum body depth of southern bluefin tuna (Thunnus maccoyii) with a stereo-video camera system. Fish Res 63:315-326

> Haury LR, Briscoe G, Orr MH (1979) Tidally generated internal wave packets in Massachusetts Bay. Nature 278: 312-317

> Hazen EL, Craig JK, Good CP, Crowder LB (2009a) Vertical distribution of fish biomass in hypoxic waters on the Gulf of Mexico shelf. Mar Ecol Prog Ser 375:195-207

- Hazen EL, Friedlaender AS, Thompson MA, Ware CR, Weinrich MT, Halpin PN, Wiley DN (2009b) Fine-scale prey aggregations and foraging ecology of humpback whales Megaptera novaeangliae. Mar Ecol Prog Ser 395:75-89

> Herman AW (1992) Design and calibration of a new optical plankton counter capable of sizing small zooplankton. Deep-Sea Res A 39:395-415

Herman AW (2001) A review of OPC and an introduction to the next generation of OPC: the laser OPC. In: Zhou M, Tande K (eds) Optical plankton counter workshop, GLOBEC rep 17. GLOBEC International Project Office, Plymouth, p 3-6. Available at: http://www.globec.org/ index.php?act=downloads \&view $=$ item $\&$ did $=73$

$>$ Hewitt RP, Demer DA (2000) The use of acoustic sampling to estimate the dispersion and abundance of euphausiids, with an emphasis on Antarctic krill, Euphausia superba. Fish Res 47:215-229

Holliday DV (1977a) Extracting bio-physical information from the acoustic signature of marine organisms. In: Anderson NR, Zahuranec BJ (eds) Oceanic sound scattering prediction. Plenum Press, New York, NY, p 619-624

Holliday DV (1977b) The use of swimbladder resonance in the sizing of schooled pelagic fish. Rapp P-V Reun-Cons Int Explor Mer 170:130-135

Holliday DV (2009) Technology for evaluating marine ecosystems in the early twenty-first century. In: Beamish RJ, Rothschild BJ (eds) The future of fisheries science in North America. Springer Science, Dordrecht, p 283-311

Holliday DV, Pieper RE, Kleppel GS (1989) Determination of zooplankton size and distribution with multifrequency acoustic technique. J Cons Int Explor Mer 46:52-61

Holliday DV, Donaghay PL, Greenlaw CF, Napp JM, Sullivan JM (2009) High-frequency acoustics and bio-optics in ecosystems research. ICES J Mar Sci 66:974-980

Honkalehto T, Jones D, McCarthy A, McKelvey D, Guttorm- 
sen M, Williams K, Williamson N (2009) Results of the echo integration-trawl survey of walleye pollock (Theragra chalcogramma) on the US and Russian Bering Sea Shelf in June and July 2008, Tech Mem NMFS-AFSC194. National Oceanic and Atmospheric Administration, Washington, DC, available at: http://www.afsc.noaa. gov/Publications/AFSC-TM/NOAA-TM-AFSC-194.pdf

Honkalehto TH, Ressler PH, Towler RH, Wilson CD (2011) Using acoustic data from fishing vessels to estimate walleye pollock (Theragra chalcogramma) abundance in the eastern Bering Sea. Can J Fish Aquat Sci 68:1231-1242

Ianelli JN, Barbeaux S, Honkalehto T, Kotwicki S, Aydin K, Williamson N (2010) Assessment of the walleye pollock stock in the Eastern Bering Sea. Stock assessment and fishery evaluation report for the groundfish resources of the Bering Sea/Aleutian Islands regions. North Pacific Fishery Management Council, Anchorage, AK, p 49-148. Available at www.afsc.noaa.gov/refm/docs/2009/EBS pollock.pdf

ICES (International Council for the Exploration of the Sea) (2000) Report on echo trace classification. ICES Coop Res Rep 238. ICES, Copenhagen

ICES (2007a). Acoustic seabed classification of marine physical and biological landscapes. ICES Coop Res Rep 286. ICES, Copenhagen

ICES (2007b) Collection of acoustic data from fishing vessels. ICES Coop Res Rep 287. ICES, Copenhagen

ICES (2009) Report of the working group on anchovy and sardine (WGANSA). 15-20 June 2009, ICES, Copenhagen. ICES CM 2009/ACOM:13

ICES (2010) Report of the study group on fish avoidance of research vessels (SGFARV). 26-27 April 2010, San Diego, CA. ICES CM 2010/SSGESST:10

> Jaffe JS, Ohman MD, De Robertis A (1998) OASIS in the sea: measurement of the acoustic reflectivity of zooplankton with concurrent optical imaging. Deep-Sea Res II 45: 1239-1253

> Jech JM, Michaels WM (2006) A multifrequency method to classify and evaluate fisheries acoustics data. Can J Fish Aquat Sci 63:2225-2235

> Jeffrey SW, Wright SW, Zapata M (1999) Recent advances in HPLC pigment analysis of phytoplankton. Mar Freshw Res 50:879-896

Jennings S (2007) Reporting and advising on the effects of fishing. Fish Fish 8:269-276

> Kang M, Fursawa M, Miyashita K (2002) Effective and accurate use of difference in mean volume backscattering strength to identify fish and plankton. ICES J Mar Sci 59: 794-804

Kang D, Shin HC, Lee YH, Kim Y, Kim S (2005) Acoustic estimate of the krill (Euphausia superba) density between South Shetland Islands and South Orkney Islands, Antarctica, during 2002/2003 austral summer. Ocean Polar Res 27:75-86

Karp WA, Walters GE (1994) Survey assessment of semipelagic gadoids: the example of walleye pollock, Theragra chalcogramma in the Eastern Bering Sea. Mar Fish Rev 56:8-22

Kempf A, Dingsør GE, Huse G, Vinther M, Floeter J, Temming A (2010) The importance of predator-prey overlap: predicting North Sea cod recovery with a multispecies assessment model. ICES J Mar Sci 67:1989-1997

Kloser RJ, Ryan TE, Young JW, Lewis ME (2009) Acoustic observations of micronekton fish on the scale of an ocean basin: potential and challenges. ICES J Mar Sci 66: 998-1006

Korneliussen RJ, Ona E (2003) Synthetic echograms generated from the relative frequency response. ICES J Mar Sci 60:636-640

Korneliussen RJ, Heggelund Y, Eliassen IK, Oye OK, Knutsen T, Dalen J (2009) Combining multibeam-sonar and multifrequency-echosounder data: examples of the analysis and imaging of large euphausiid schools. ICES J Mar Sci 66:991-997

Koslow JA (2009) The role of acoustics in ecosystem-based fishery management. ICES J Mar Sci 66:966-973

Kracker LM, Taylor JC, Ebert EF, Battista TA, Menza C (2011) Integration of fisheries acoustics surveys and bathymetric mapping to characterize midwater-seafloor habitats of US Virgin Islands and Puerto Rico (20082010). Tech mem NOS NCCOS 130. National Oceanic and Atmospheric Administration, Washington, DC

> Lavery AC, Schmitt RW, Stanton TK (2003) High-frequency acoustic scattering from turbulent oceanic microstructure: the importance of density fluctuations. J Acoust Soc Am 114:2685-2697

Lawson GL, Rose GA (1999) The importance of detectability to acoustic surveys of semi-demersal fish. ICES J Mar Sci $56: 370-380$

Lebourges-Dhaussy A, Coetzee J, Hutchings L, Roudaut G, Nieuwenhuys C (2009) Zooplankton spatial distribution along the South African coast studied by multifrequency acoustics, and its relationships with environmental parameters and anchovy distribution. ICES J Mar Sci 66: 1055-1062

Lehodey P, Murtugudde R, Senina I (2010) Bridging the gap from ocean models to population dynamics of large marine predators: a model of mid-trophic functional groups. Prog Oceanogr 84:69-84

Leyequien E, Verrelst J, Slot M, Schaepman-Strub G, Heitkönig IMA, Skidmore A (2007) Capturing the fugitive: applying remote sensing to terrestrial animal distribution and diversity. Int J Appl Earth Obs 9:1-20

> Link JS, Brodziak JKT, Edwards SF, Overholtz WJ and others (2002) Marine ecosystem assessment in a fisheries management context. Can J Fish Aquat Sci 59:1429-1440

> Livingston PA, Aydin K, Boldt J, Ianelli J, Jurado-Molina J (2005) A framework for ecosystem impacts assessment using an indicator approach. ICES J Mar Sci 62:592-597

> Long LV, Aoyama T (1985) Photographic measurement for obtaining the length, aspect and bearing of free-swimming fish from their spatial position. Bull Jpn Soc Sci Fish 51:191-195

Mackey MD, Mackey DJ, Higgins HW, Wright SW (1996) CHEMTAX - a program for estimating class abundances from chemical markers: application to HPLC measurements of phytoplankton. Mar Ecol Prog Ser 144: 265-283

Mackinson S, Freeman S, Flatt R, Meadows B (2004) Improved acoustic surveys that save time and money: integrating fisheries and ground-discrimination acoustic technologies. J Exp Mar Biol Ecol 305:129-140

> MacLennan DN, Fernandes PG, Dalen J (2002) A consistent approach to definitions and symbols in fisheries acoustics. ICES J Mar Sci 59:365-369

> Makris NC, Ratilal P, Jagannathan S, Gong Z and others (2009) Critical population density triggers rapid formation of vast oceanic fish shoals. Science 323:1734-1737 
Massé J (1996) Acoustic observations in the Bay of Biscay: schooling, vertical distribution, species assemblages and behaviour. Sci Mar 60(Suppl 2):227-234

McClatchie S, Thorne RE, Grimes P, Hanchet S (2000) Ground truth and target identification for fisheries acoustics. Fish Res 47:173-191

Mellin C, Delean S, Caley J, Edgar G, Meekan M, Pitcher R, Przeslawski R, Williams A, Bradshaw C (2011) Effectiveness of biological surrogates for predicting patterns of marine biodiversity: a global meta-analysis. PLoS ONE 6: e20141

Methot RD (2009) Stock assessment: operational models in support of fisheries management. In: Beamish RJ, Rothschild BJ (eds) The future of fisheries science in North America. Springer Science, Dordrecht, p 137-165

> Misund OA (1997) Underwater acoustics in marine fisheries and fisheries research. Rev Fish Biol Fish 7:1-34

> Misund OA, Aglen A (1992) Swimming behaviour of fish schools in the North Sea during acoustic surveying and pelagic trawl sampling. ICES J Mar Sci 49:325-334

Misund OA, Vilhjálmsson H, Jákupsstovu SHÍ, Røttingen I and others (1997) Distribution, migration and abundance of Norwegian spring spawning herring in relation to the temperature and zooplankton biomass in the Norwegian Sea as recorded by coordinated surveys in spring and summer 1996. Sarsia 83:117-127

> Moline MA, Benoit-Bird KJ, Robbins IC, Schroth-Miller M, Waluk CM, Zelenke B (2010) Integrated measurements of acoustical and optical thin layers II: horizontal length scales. Cont Shelf Res 30:29-38

Muiño R, Carrera P, Petitgas P, Beare DJ and others (2003) Consistency in the correlation of school parameters across years and stocks. ICES J Mar Sci 60:164-175

Nakken O (ed) (2008) Norwegian spring-spawning herring and northeast Arctic cod: 100 years of research and management. Tapir Academic Press, Trondheim

O'Driscoll RL, Gauthier S, Devine JA (2009) Acoustic estimates of mesopelagic fish: As clear as day and night? ICES J Mar Sci 66:1310-1317

> Oeberst R, Klenz B, Gröhsler T, Dickey-Collas M, Nash RDM, Zimmermann C (2009) When is year-class strength determined in western Baltic herring? ICES J Mar Sci 66: 1667-1672

Ona E, Mitson RB (1996) Acoustic sampling and signal processing near the seabed: the dead zone revisited. ICES J Mar Sci 53:677-690

Osborn J (1997) Analytical and digital photogrammetry. In: Parrish JK, Hamner WM (eds) Animal groups in three dimensions. Cambridge University Press, Cambridge, p 36-60

Paramo J, Roa R (2003) Acoustic-geostatistical assessment and habitat-abundance relations of small pelagic fish from the Colombian Caribbean. Fish Res 60:309-319

> Paramo J, Quiñones RA, Ramirez A, Wiff R (2003) Relationship between abundance of small pelagic fishes and environmental factors in the Colombian Caribbean Sea: an analysis based on hydroacoustic information. Aquat Living Resour 16:239-245

Pauly D, Christensen V, Dalsgaard J, Froese R, Torres F Jr (1998) Fishing down marine food webs. Science 279: 860-863

Pauly D, Christensen V, Walters C (2000) Ecopath, Ecosim, and Ecospace as tools for evaluating ecosystem impact of fisheries. ICES J Mar Sci 57:697-706
Peltonen $\mathrm{H}$, Luoto M, Pääkkönen JP, Karjalainen M, Tuomaala A, Pönni J, Viitasalo M (2007) Pelagic fish abundance in relation to regional environmental variation in the Gulf of Finland, northern Baltic Sea. ICES J Mar Sci 64:487-495

Petitgas P (1998) Biomass-dependent dynamics of fish spatial distributions characterized by geostatistical aggregation curves. ICES J Mar Sci 55:443-453

Petitgas P, Massé J, Bourriau P, Bellois P and others (2006) Hydro-plankton characteristics and their relationship with sardine and anchovy distributions on the French shelf of the Bay of Biscay. Sci Mar 70(S1):161-172

Popper AN, Plachta DTT, Mann DA, Higgs D (2004) Response of clupeid fish to ultrasound: a review. ICES J Mar Sci 61:1057-1061

Purcell JE, Uye S, Lo W (2007) Anthropogenic causes of jellyfish blooms and their direct consequences for humans: a review. Mar Ecol Prog Ser 350:153-174

Quinn TJ (2003) Ruminations on the development and future of population dynamics models in fisheries. Nat Res Model 16:341-392

> Radenac MH, Plimpton PE, Lebourges-Dhaussy A, Commien L, McPhaden MJ (2010) Impact of environmental forcing on the acoustic backscattering strength in the Equatorial Pacific: diurnal, lunar, intraseasonal, and interannual variability. Deep-Sea Res I 57:1314-1328

Ressler PH, Fleischer GW, Wespestad VG, Harms J (2009) Developing a commercial-vessel-based stock assessment survey methodology for monitoring the US west coast widow rockfish (Sebastes entomelas) stock. Fish Res 99: 63-73

Ressler PH, De Robertis A, Warren JD, Smith JN, Kotwicki S (in press) Using an acoustic index of euphausiid abundance to understand trophic interactions in the Bering Sea ecosystem. Deep-Sea Res II

Reynisson P, Sigurdsson P (1996) Diurnal variation in acoustic intensity and target strength measurements of oceanic redfish (Sebastes mentella) in the Irminger Sea. ICES CM 1996/G:25

Rice JC (2009) A generalization of the three-stage model for advice using the precautionary approach in fisheries, to apply broadly to ecosystem properties and pressures. ICES J Mar Sci 66:433-444

Rice JC, Rochet MJ (2005) A framework for selecting a suite of indicators for fisheries managment. ICES J Mar Sci 62: 516-527

Rocchini D, Balkenhol N, Carter GA, Foody GM and others (2010) Remotely sensed spectral heterogeneity as a proxy of species diversity: recent advances and open challenges. Ecol Inform 5:318-329

Rochet MJ, Trenkel VM (2003) Which community indicators can measure the impact of fishing? A review and proposals. Can J Fish Aquat Sci 60:86-99

Rochet MJ, Trenkel VM (2009) Why and how could indicators be used in an ecosystem approach to fisheries management? In: Beamish RJ, Rothschild, BJ (eds) The future of fisheries science in North America. Springer Science, Dordrecht, p 209-226

Rochet MJ, Trenkel VM, Bellail R, Coppin F and others (2005) Combining indicator trends to assess ongoing changes in exploited fish communities: diagnostic of communities off the coasts of France. ICES J Mar Sci 62: 1647-1664

Rochet MJ, Trenkel VM, Carpentier A, Coppin F and others 
(2010) Do changes in environmental and fishing pressures impact marine communities? An empirical assessment. J Appl Ecol 47:741-750

Sameoto D, Cochrane N, Herman A (1993) Convergence of acoustic, optical, and net-catch estimates of euphausiid abundance: use of artificial light to reduce net avoidance. Can J Fish Aquat Sci 50:334-346

Sameoto D, Wiebe P, Runge J, Postel L, Dunn J, Miller C, Coombs S (2000) Collecting zooplankton. In: Harris R, Wiebe P, Lenz J, Skjoldal HR, Huntley M (eds) ICES zooplankton methodology manual. Academic Press, San Diego, CA, p 55-81

Scalabrin C, Marfia C, Boucher J (2009) How much fish is hidden in the surface and bottom acoustic blind zones? ICES J Mar Sci 66:1355-1363

Shannon LJ, Moloney CL, Jarre A, Field JG (2003) Trophic flows in the southern Benguela during the 1980s and 1990s. J Mar Syst 39:83-116

Shin YJ, Cury P (2001) Exploring fish community dynamics through size-dependent trophic interactions using a spatialized individual-based model. Aquat Living Resour 14: 65-80

Shin YJ, Rochet MJ, Jennings S, Field JG, Gislason H (2005) Using size-based indicators to evaluate the ecosystem effects of fishing. ICES J Mar Sci 62:384-396

Simmonds EJ, MacLennan DN (2005) Fisheries acoustics: theory and practice, 2nd edn. Blackwell Publishing, Oxford

Southall BL, Nowacek DP (2009) Acoustics in marine ecology: innovation in technology expands the use of sound in ocean science. Mar Ecol Prog Ser 395:1-3

Stoner AW, Ryer CH, Parker SJ, Auster PJ, Wakefield WW (2008) Evaluating the role of fish behavior in surveys conducted with underwater vehicles. Can J Fish Aquat Sci 65:1230-1243

Suchman CL, Daly EA, Keister JE, Peterson WT, Brodeur RD (2008) Feeding patterns and predation potential of scyphomedusae in a highly productive upwelling region. Mar Ecol Prog Ser 358:161-172

Swartzman G, Brodeur R, Napp J, Walsh D and others (1999) Relating spatial distributions of acoustically determined patches of fish and plankton: data viewing, image analysis, and spatial proximity. Can J Fish Aquat Sci 56(Suppl 1):188-198

Taylor JC, Rand PS (2003) Spatial overlap and distribution of anchovies (Anchoa spp.) and copepods in a shallow stratified estuary. Aquat Living Resour 16:191-196

Taylor JC, Rand PS, Jenkins J (2007) Swimming behaviour of juvenile anchovies (Anchoa spp.) in an episodically hypoxic estuary: implications for individual energetics and trophic dynamics. Mar Biol 152:939-957

Thomas GL, Thorne RE (2003) Acoustical-optical assessment of Pacific herring and their predator assemblage in Prince William Sound, Alaska. Aquat Living Resour 16: 247-253

> Toresen R, Gjøsæter H, De Barros P (1998) The acoustic method as used in the abundance estimation of capelin (Mallotus villosus Müller) and herring (Clupea harengus Linné) in the Barents Sea. Fish Res 34:27-37

Totland A, Johansen GO, Godø OR, Ona E, Torkelsen T (2009) Quantifying and reducing the surface blind zone and the seabed dead zone using new technology. ICES J Mar Sci 66:1370-1376

> Trenkel VM, Lorance P, Mahevas S (2004) Do visual transects provide true population density estimates for deepwater fish? ICES J Mar Sci 61:1050-1056

Trenkel VM, Mazauric V, Berger L (2008) The new fisheries multibeam echosounder ME70: description and expected contribution to fisheries research. ICES J Mar Sci 65: 645-655

> Trenkel VM, Berger L, Bourguignon S, Doray M and others (2009) Overview of recent progress in fisheries acoustics made by Ifremer with examples from the Bay of Biscay. Aquat Living Resour 22:433-445

Tsagarakis K, Coll M, Giannoulaki M, Somarakis S, Papaconstantinou C, Machias A (2010) Food-web traits of the North Aegean Sea ecosystem (Eastern Mediterranean) and comparison with other Mediterranean ecosystems. Estuar Coast Shelf Sci 88:233-248

Tugores P, Giannoulaki M, Iglesias M, Bonanno A and others (2010) Habitat suitability modeling for sardine in a highly diverse ecosystem: the Mediterranean Sea. ICES annual conference, Sep 2010, Nantes, France. ICES CM R:09

Wiebe PH, Benfield MC (2003) From the Hensen net toward four-dimensional biological oceanography. Prog Oceanogr 56:7-136

Williams K, Punt AE, Wilson CD, Horne JK (2010a) Lengthselective retention of walleye pollock, Theragra chalcogramma, by midwater trawls. ICES J Mar Sci 68: 119-129

Williams K, Rooper C, Towler R (2010b) Use of stereo camera systems for assessment of rockfish abundance in untrawlable areas and for recording pollock behavior during midwater trawls. Fish Bull 108:352-362

Williams K, Towler R, Wilson CD (2010c) Cam-Trawl: a combination trawl and stereo-camera system. Sea Technol 51:45-51

> Woillez M, Poulard JC, Rivoirard J, Petitgas P, Bez N (2007) Indices for capturing spatial patterns and their evolution in time, with application to European hake (Merluccius merluccius) in the Bay of Biscay. ICES J Mar Sci 64: 537-550

Yoklavich MM, Grimes CB, Wakefield WW (2003) Using laser line scan imaging technology to assess deepwater seafloor habitats in the Monterey Bay National Marine Sanctuary. MTS Journal 37:18-26

Yule DL, Adams JV, Stockwell JD, Gorman OT (2007) Using multiple gears to assess acoustic detectability and biomass of fish species in Lake Superior. N Am J Fish Manag 27:106-126

Zador S, Gaichas S (eds) (2010) Ecosystem considerations for 2011. In: Stock assessment and fishery evaluation report for the groundfish resources of the Bering Sea/Aleutian Islands regions, App C. North Pacific Fishery Management Council, Anchorage, AK

Zwolinski JP, Oliveira PB, Quintino V, Stratoudakis Y (2010) Sardine potential habitat and environmental forcing off western Portugal. ICES J Mar Sci 67:1553-1564

> Zwolinski JP, Emmet RL, Demer DA (2011) Predicting habitat to optimize sampling of Pacific sardine (Sardinops sagax). ICES J Mar Sci 68:867-879 
Appendix 1. Construction of Fig. 1: Spatio-temporal scope of a single observation by various sampling devices and sensors

All values in Fig. 1 are the minimum and maximum volumes and time required for a single observation with the sampling devices and sensors are listed below. We do not account for repeated measurements over space and time. Polygons in Fig. 1 were drawn such that the upper right corner represents maximum spatial and temporal values and the lower left corner the minimum spatial and temporal values.

\section{Active acoustics}

Maximum volume and time was derived from the Ocean Acoustic Waveguide Remote Sensing (OAWRS) system (Makris et al. 2009). Horizontal extent is approximately $100 \mathrm{~km}$ in diameter. Vertical extent is dependent on water depth. For this estimate, we assumed $100 \mathrm{~m}$. Two-way travel time for this observation is $\sim 70 \mathrm{~s}$. We did not include basin-scale or ocean-scale measurements such as those conducted to monitor climate change (Baggeroer et al. 1998). Minimum volume was derived from the Dualfrequency IDentification SONar (DIDSON; Sound Metrics). The DIDSON uses acoustic lens technology to acquire high-resolution acoustic images. The DIDSON system can transmit on the order of 10 pings $\mathrm{s}^{-1}(0.1 \mathrm{~Hz})$. Volume is based on a $14 \times 0.3^{\circ}$ beam with $1.5 \mathrm{~cm}$ range resolution at $1 \mathrm{~m}$ range.

\section{Visual optics}

Visual optics includes cameras and video systems. Maximum sampling volume is based on a wide-angle lens $(96 \times$ $78^{\circ}$; Deep Sea Power and Light Super SeaCam 5000) and detection of objects out to $30 \mathrm{~m}$. Sampling volume is modelled as pyramidal $(\mathrm{V}=\mathrm{Bh} / 3$, where $\mathrm{B}$ is the area of the base and $h$ is the distance). Minimum sampling volume is assumed to be $5 \mathrm{~mm}^{3}$. The maximum frame rate for acquiring data is $\sim 30$ frames $\mathrm{s}^{-1}$.

\section{Laser technologies}

Laser technologies consist predominantly of the laser line scanner (LLS; Yoklavich et al. 2003) and Light Detection and Ranging equipment (LIDAR; Churnside et al. 2001). The LLS scans a laser beam in the across-track direction, acquiring a 2-dimensional image of targets in the water column and on the sea floor. The LLS has a $70^{\circ}$ swath; its sampling volume depends on the height of the system above the seafloor, but it is towed as close to the bottom as $\sim 3 \mathrm{~m}$. In constructing Fig. 1 we used a $4 \mathrm{~m}$ swath and $7 \mathrm{~mm}$ along-track resolving scale. LIDAR essentially generates a column of light from an airborne vehicle (usually an airplane) that illuminates targets in the water. LIDAR can penetrate to about $50 \mathrm{~m}$ in clear water; a $10 \mathrm{~ns}$ pulse generates a 'column' $5 \mathrm{~m}$ in diameter.

\section{Trawl}

Trawls for fishing come in a wide variety of types, and are fished for a wide variety of purposes and in a wide variety of habitats. It is therefore difficult to set a minimum and maximum. However, there are commonalities among trawls for scientific uses. As examples, we selected a bottom trawl from the northeast United States for the minimum, and a large pelagic trawl used in Iceland (Reynisson \& Sigurdsson 1996) for the maximum. The 'Yankee 36' net has been used for approximately $40 \mathrm{yr}$ in the northeast United States for fisheries-independent sampling (Azarovitz 1981). Tow duration was $30 \mathrm{~min}$ at about 3.8 knots $\left(1.9 \mathrm{~m} \mathrm{~s}^{-1}\right)$. The mouth opening was $\sim 2 \mathrm{~m}$ vertical $\times 10.5 \mathrm{~m}$ horizontal. A Gloria-type Hampidjan pelagic trawl was used to sample deep-water oceanic redfish Sebastes spp. (Reynisson \& Sigurdsson 1996). A nominal opening when towed at 3 knots $\left(1.5 \mathrm{~m} \mathrm{~s}^{-1}\right)$ is $\sim 70 \mathrm{~m}$ vertical by $95 \mathrm{~m}$ horizontal. Tow duration was set at $60 \mathrm{~min}$.

\section{Zooplankton sampling}

Several types of sampling gear are used to collect zooplankton, but they fall into 3 general categories: (1) conventional gear, (2) multiple net, and (3) electronic optical (Sameoto et al. 2000). Sameoto et al. (2000) provide a summary of the resolving scale and operating ranges of these types of gear.

For the zooplankton net, the minimum was derived by taking the resolving scale of a Multiple Opening/Closing Net and Environmental Sensing System (MOCNESS) at $1 \mathrm{~m}^{2}$ and towing at $1 \mathrm{~m} \mathrm{~s}^{-1}$ for $30 \mathrm{~min}$. The maximum was derived by taking the resolving scale of the larger MOC$\operatorname{NESS}(3 \mathrm{~m} \times 3 \mathrm{~m})$ and towing at $1 \mathrm{~m} \mathrm{~s}^{-1}$ for $60 \mathrm{~min}$.

For the optical sensors, the minimum was derived by taking the spatial resolving scale of a video plankton recorder $(\mathrm{VPR}, 0.01 \mathrm{~m}$ vertical $\times 5 \mathrm{~m}$ horizontal), acquiring data at 2 frames $\mathrm{s}^{-1}(0.5 \mathrm{~Hz})$, and towing at 5 knots 
Appendix 1 (continued)

$\left(2.5 \mathrm{~m} \mathrm{~s}^{-1}\right)$. The maximum was derived by taking the maximum spatial resolving scale of an optical plankton counter $(1 \mathrm{~m} \times 1 \mathrm{~m})$, acquiring data at 1 frame $\mathrm{s}^{-1}$, and towing at 5 knots $\left(2.5 \mathrm{~m} \mathrm{~s}^{-1}\right)$.

\section{Pumps}

Pumps are used to sample zooplankton and ichthyoplankton, including fish larvae. The minimum was derived from the resolving scale of a pump $(0.1 \mathrm{~m} \times 0.1 \mathrm{~m})$, and sampling at 1 time s $\mathrm{s}^{-1}$ on a vessel moving at 10 knots $\left(5 \mathrm{~m} \mathrm{~s}^{-1}\right)$. The maximum was given in Sameoto et al. (2000) as $2.8 \mathrm{~m}^{3} \mathrm{~min}^{-1}$.

\section{Water bottles}

As the name suggests, water bottles are used to capture water samples for chemical and biological (e.g. zooplankton and phytoplankton) analysis. The minimum is $1 \times 10^{-3} \mathrm{~m}^{3}$ and the maximum is $1 \mathrm{~m}^{3}$. We assume $1 \mathrm{~s}$ per sample.

\section{Physical environment sensors}

Sensors to measure the physical environment (e.g. temperature, conductivity, pressure, light attenuation, turbulence, etc.) are generally point measurements. We estimate the sampling volume of these to be approximately $1 \mathrm{~cm}^{3}$.
Table A1. Minimum and maximum sampling volumes and time required for a single observation by different sampling technologies

\begin{tabular}{|c|c|c|c|c|}
\hline \multirow[t]{2}{*}{ Sensor } & \multicolumn{2}{|c|}{-Volume $\left(\mathrm{m}^{3}\right)$} & \multicolumn{2}{|c|}{ _Time $(\mathrm{s})$} \\
\hline & Min. & Max. & Min. & Max. \\
\hline Active acoustics & $1.9 \times 10^{-5}$ & $7.9 \times 10^{11}$ & $1.0 \times 10^{-1}$ & $6.7 \times 10^{1}$ \\
\hline Visual optics & $1.3 \times 10^{-7}$ & $3.2 \times 10^{4}$ & $1.0 \times 10^{-2}$ & $3.0 \times 10^{-2}$ \\
\hline Trawl & $7.2 \times 10^{4}$ & $3.6 \times 10^{7}$ & $1.8 \times 10^{3}$ & $3.6 \times 10^{3}$ \\
\hline Zooplankton nets & $1.8 \times 10^{3}$ & $3.2 \times 10^{4}$ & $1.8 \times 10^{3}$ & $3.6 \times 10^{3}$ \\
\hline Zooplankton optics & $6.3 \times 10^{-2}$ & $2.5 \times 10^{0}$ & $5.0 \times 10^{-1}$ & $1.0 \times 10^{0}$ \\
\hline Pumps & $5.0 \times 10^{-2}$ & $2.8 \times 10^{0}$ & $1.0 \times 10^{0}$ & $6.0 \times 10^{1}$ \\
\hline Water bottles & $1.0 \times 10^{-3}$ & $1.0 \times 10^{0}$ & $1.0 \times 10^{0}$ & $1.0 \times 10^{0}$ \\
\hline Laser & $8.8 \times 10^{-2}$ & $9.8 \times 10^{2}$ & $1.0 \times 10^{-2}$ & $3.3 \times 10^{-2}$ \\
\hline Physical sensors & $1.0 \times 10^{-6}$ & $1.0 \times 10^{-6}$ & $1.0 \times 10^{-1}$ & $1.0 \times 10^{0}$ \\
\hline Satellite & $6.3 \times 10^{4}$ & $7.8 \times 10^{6}$ & $4.4 \times 10^{-2}$ & $9.0 \times 10^{-1}$ \\
\hline
\end{tabular}

Submitted: June 8, 2011; Accepted: September 23, 2011 Proofs received from author(s): November 24, 2011
Editorial responsibility: Matthias Seaman, Oldendorf/Luhe, Germany
Satellites provide wide-area coverage at fairly high resolution in a single snapshot. Satellite measurements do not penetrate below the surface and we set this limit to $1 \mathrm{~m}$ depth. Barbini et al. (2006) provide range and resolution of 3 satellite systems for ocean measurements: SeaWiFS, MODIS, and MERIS. MODIS has the finest resolution, at $0.25 \mathrm{~km}$. SeaWiFS has the maximum footprint, covering a $2.8 \mathrm{~km}$ swath. We do not include satellites that can image an entire hemisphere. 